\title{
Response of Intestinal Mucosa to Trichinosis in immunized and non- immunized Albino Rat
}

\author{
Azza A. Elnokaly and Abdel-Mawgoud A. Ismaeil \\ Departments of Parasitology and Histology, Boys and Girls Faculties of Medicine, \\ AlAzhar University
}

\begin{abstract}
The intestinal mucosa is reported to be greatly affected by infestation by Trichinella spiralis. The infestation by the worm is also controlled by intestinal tissue factors including cytokines and immune response. Vaccination with larval muscle antigen was reported to be of limited effect. However, vaccination with adult worm crude antigen may infer better protection. The aim of this work is to relate the histological, morphometric and immunological response of the intestinal mucosa of T.spiralis infested rat to worm burden, female fecundity and worm expulsion before and after immunization with crude antigen of the adult worm. This relationship is expected to give better evaluation of immunization by this antigen.

45 adult albino rats were allotted among three equal groups: control, T.spiralis infested and immunized infested group. Infection was done by 300 freshly isolated infective T.spiralis larvae. Five rats from each group were sacrificed at the end of the first, second and third week of infestation. The efficacy of immunization was assessed weekly by measuring adult worm burden and female fecundity, in relation to changes in the histological appearance, relative villus length, number of goblet, and mast cells and the amount of histamine in the intestine.

The results indicated that the worm burden was at its peak by the end of the first week after infestation. The mean protection value due to immunization in this parameter was $67 \%$. Immunization resulted in a protection value relative to larval emergence of $38 \%$. Maximum changes in the host tissue parameters were detected a week after that of worm burden. Measurement of the host intestinal response represented $78 \%$ change in villus/crypt ratio, $13.3 \%$ in number of goblet cells in the villus and 16.22 in the crypts, $22.5 \%$ in mast cell number and $16.8 \%$ in histamine content. The results indicate that immunization by crude antigen of the adult T.spiralis has a protective effect of the intestinal mucosa of the host due to inhibition of worm vitality and larval emergence. Mast cell production of histamine and goblet cell secretion of mucins could also play a role in protection.
\end{abstract}

\section{Introduction}

Trichinosis remains an important zoonotic food-born parasitic disease of world wide distribution (Murrell, 2001). Trichinella spiralis parasitizes many mammals including man. The pig is considered the main component of the epidemoepizootologic chain (Leiby et al., 1990).

Although in Egypt pork meat is not a common dish due to religious instructions, yet the risk of infection is still there, since sheep proved to be a source for human trichinosis (Rosa et al., 1992; Kim, 1993; and Theodoropoulos et al., 2000). Recently, Trichonella larvae have been also detected in ostriches (Piergilli-Foretti et al., 2001) and horses (Viveros et al., 2001). The presence of Trichinella in these animals followed the use of proteins of animal origin in breeding herbivorous animals, which is now a common practice in many countries(Pozio et al., 2001) including Egypt.

The relationship between parasites and hosts can be considered according to the concept that the host is an environment providing microhabitats for parasites to exploit (Rollinson and Anderson, 1985). Parasites divert resources from the host to their own use. So, the host is under strong selection pressure to stop, or at least, reduce this drain of his resources. One result of these pressures has been the evolution of 
acquired immunity which can introduce changes in the environment of the parasite that are disadvantageous to it, and thus, help to restore the balance in favor of the host (Walkelin, 1993). There is a possible role of intestinal epithelial cells of the host in the protective immune response to T.spiralis. This role has been developed from observation of modified epithelial cell structure and function during a challenge infection. These changes included molecular and functional changes represented by reduced wheat germ lectin binding to the epithelial brush border membrane in infected rats (Bell, 1998), reduced hexose transport (Hessel et al., 1982), increased potential difference across epithelial tight junctions (Russell\&Castro,1985), and chloride ion secretion, which is linked to a change from fluid uptake to net fluid secretion by enterocytes (Bell,1998). The functional changes in epithelial cells described in these studies have been linked to the immune system through immune serum transfer (Bell,1998). Immunity seems to play a role in expulsion of the adult worms of T.spiralis by the host. Although, it seems to be an ambiguous multi factorial process, but involvement of certain antibodies and cytokines has been well recognized lately (Bell,1998).

Although immunization has proven to be one of the most powerful weapons for prevention of infectious diseases, little prospect exists for the development of vaccines for parasitic infections ( Gamble and Murrell, 1987). There is no doubt that the development of successful vaccination against human trichinosis is greatly needed. Prior infection with T.spiralis results in nearly complete immunity to challenge infection (Murrell, 1985). Antigens derived from different life cycle stages, likewise, can induce protective immunity (Gamble, 1985). However, it was found that the protection against challenge infection using antigens derived from the muscle of the larvae was partial (Murrell and Despomier, 1984 and Gamble.1985).

The aim of this work was to study the interaction between the extent of successful infection and the structure and activity of intestinal mucosa of rats infected by
T.spiralis worm alone or after immunization by crude antigen of the adult worm.

\section{Material And Methods}

\section{Animals:}

Forty five parasite free male inbred albino rats , 8-10 weeks old were divided into 3 equal groups: Control (C), parasite infected $(\mathrm{P})$, and pre-immunized parasite infected (PI) group.

\section{Parasite:}

T.spiralis larvae were primarily obtained from infected pig diaphragm slaughtered at El-basateen abattoir, Cairo. They were maintained in the laboratory by serial passages in albino rats. Isolation of larvae from tissues was done according to Wassom et al., (1983).

\section{Antigen}

Crude adult worm antigen (AA) was prepared according to the method of Goyal and Wakelin (1993). 7 day-old adult worms were collected from experimentally infected rats. The protein content of the worm homogenate was determined according to the method of Lowery et al. (1951). Homogenates were stored in $1 \mathrm{ml}$ vials stored at $-20^{\circ} \mathrm{C}$ till use.

\section{Protocol of Immunization and Infection}

Rats of the immunized-infected group

(PI) were immunized by two subcutaneous injections of $100 \mu \mathrm{g}$ AA emulsified in complete Freund's adjuvant (CFA, Sigma). The injections were one week apart. Rats of group $(\mathrm{C})$ and $(\mathrm{P})$ were injected in the same way by antigen free solution of CFA in phosphate buffer system (PBS). One week after the last injection, each animal from groups (P) and (PI) was infected with 300 freshly isolated infective larvae of T.spiralis. (Goyal and Wakelin, 1993).

\section{Evaluation of the Efficacy of Immunization}

Five rats from each group were sacrificed after ether anaesthesia by the end of the first, second and third week after parasite 


\section{Azza A. Elnokaly \&Abdel-Mawgoud A. Ismaeil}

infection. The small intestine was dissected out free of mesentry and subjected to the following examinations:

A. Adult worm burden was performed according to the method described by Gamble (1985).

B. Female worm fecundity was performed by in vitro release of larvae by female worms (Goyal and Wakelin, 1993). Fifty adult female worms were recovered on day 7 post-infection from 5 rats of each of the $(\mathrm{P})$ and $(\mathrm{PI})$ groups. The fifty worms of each group were incubated in universal tube containing $10 \mathrm{ml}$ Hank's culture medium containing $10 \%$ fetal calf serum. The tubes then incubated for 4 hours at $37^{\circ} \mathrm{C}$. The contents were filtered through two layers of gauze. The filtrate was transferred to centrifuge tubes. Few drops of formalin were added to each tube. The filtered culture was centrifuged for 10 mins at 1000rpm. The supernatant was decanted and the pellet was resuspended in $1 \mathrm{ml}$ of PBS. The newly emerged larvae were counted in 10 aliquots of $10 \mu \mathrm{l}$. The counts were expressed as (larvae/ female/24hrs).

C. The percent protection was calculated in the immunized group according to Wang and Bell (1987).

\section{Histological Studies}

\section{Histological preparations}

A jeujenal segment was dissected from the rats of each group, approximately $6 \mathrm{~cm}$ long. The segment was divided into 3 pieces each.

The first piece was opened, washed and fixed in Carnoy fluid for $24 \mathrm{hrs}$. It was processed for paraffin embedding. $5 \mu \mathrm{m}$ sections were stained with toluidine blue for demonstration of mast cells.

The second piece was fixed in buffered formol. It was then processed prepared for paraffin embedding. Serial $5 \mu \mathrm{m}$ sections were mounted on clean slides. Slide with one section was stained by hematoxylin and eosin $(\mathrm{Hx} \& \mathrm{E})$ for general structure, and the next was stained by alcian blue - PAS (AB-PAS) stain (Mowry, 1958) for demonstration of goblet cells and characterization of the type of mucin.

\section{Quantitative Histology}

Using Hx\&E stained sections, 10 well oriented villi and crypts per rat were subjected to measurement of villus length and crypt depth using a calibrated micrometer mounted on Leitz microscope.

The alternative sections stained by AB-PAS were used to count the goblet cells in well oriented villi and crypts. The number of goblet cells per constant length using a Leitz microscope and eye piece graticule was recorded for 10 villi and crypts on each slide. Parts of the sections with well oriented villi and crypts with intact muscularis mucosa were chosen for counting goblet cells. Ten slides representing different animals of each group were counted.

Ten sections from the opened piece of jeujenum stained with toluidine blue were used to count the number of mast cells per 10 constant areas from each slide. A Leitz microscope and eye piece graticule was used..

\section{Histamine Content}

The third piece of jeujenum was used to estimate the amount of histamine in $\mu \mathrm{g} /$ $\mathrm{gm}$ of intestinal tissue. The assay was performed according to the method of Lorenz et al.(1977) using the modified fluoromrtic assay.

\section{Statistical Analysis}

Data was statistically analyzed and graphically represented using Microsoft excel.

\section{Results}

Effect of Parasite on Intestinal Villi and Crypts

\section{Histology and Histochemistry}

In Hematoxylin and eosin stained sections, the intestinal mucosa of the control shows long finger like villi projecting in the lumen and crypts in between (Plate I: 1). 
After one week of infection with the parasite, the villi became short with blunt tips (Plate I: 2). The crypts appear relatively short and the muscle layer appears thickened. In parts of the sections, the worms appear invading the villi causing damage to the epithelial layer (Plate I, 2-insert). These changes are more prominent by the second week post infection (Plate I: 3 )

In sections of the infected immunized group, the deteriorative changes appear less prominent than in the non-immunized group after one and two weeks of infection. (Plate I: 4, 5).
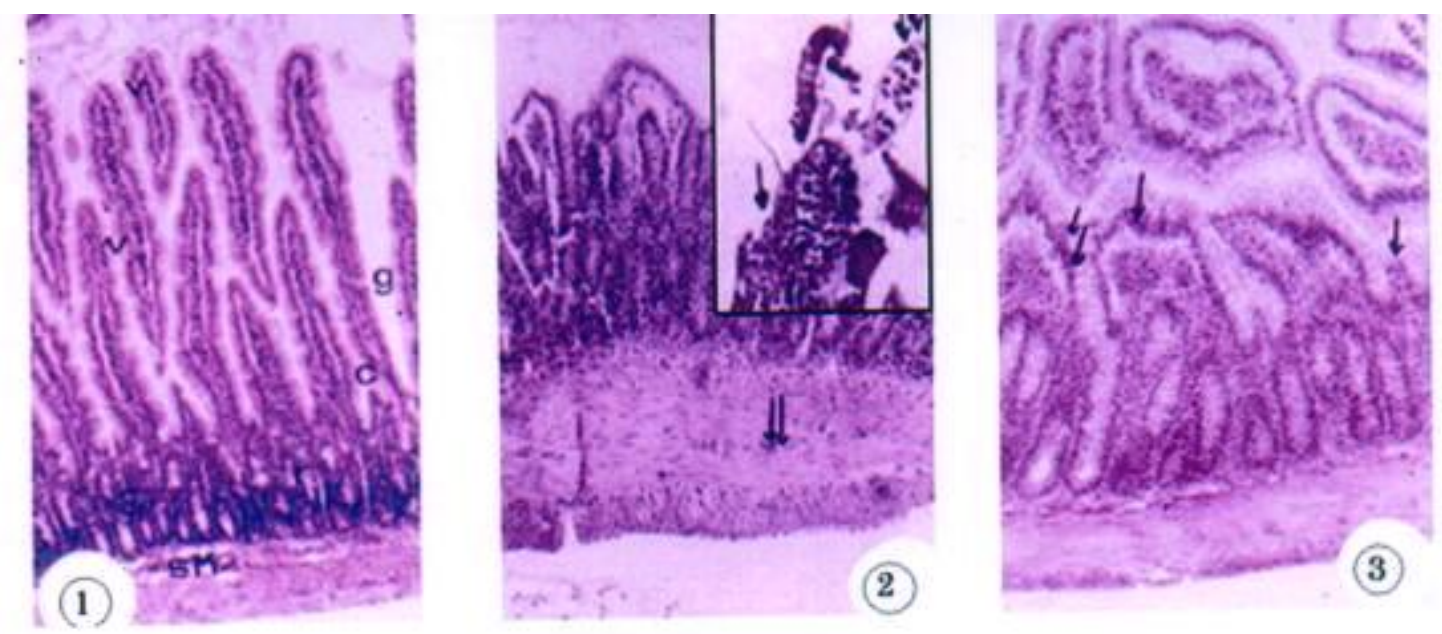
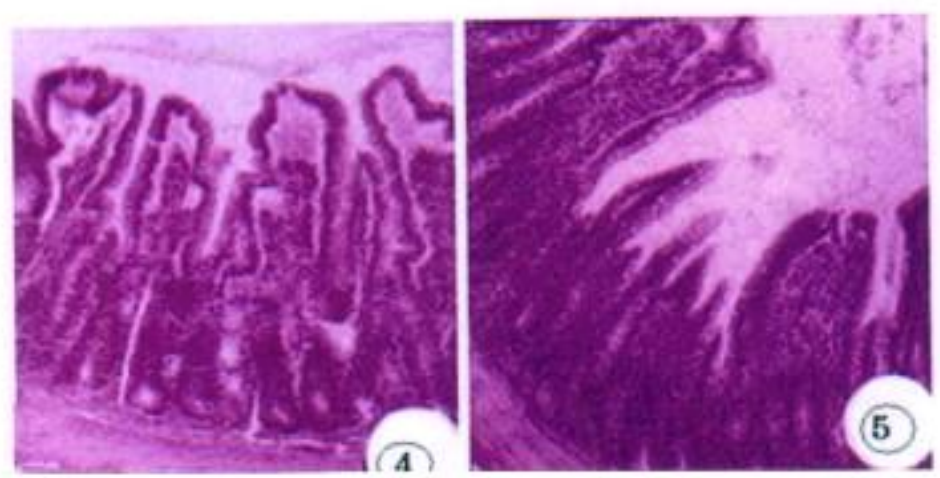

Plate I: Jejunal epithelium of 1) Control, 2) One week after worm infection: The insert represents the invasion of the epithelium by the adult worms., 3) Two weeks after infection, 4) Immunized infected group one week post infection, 5) Immunized infected two weeks post infection.

(HX, E, X100) 


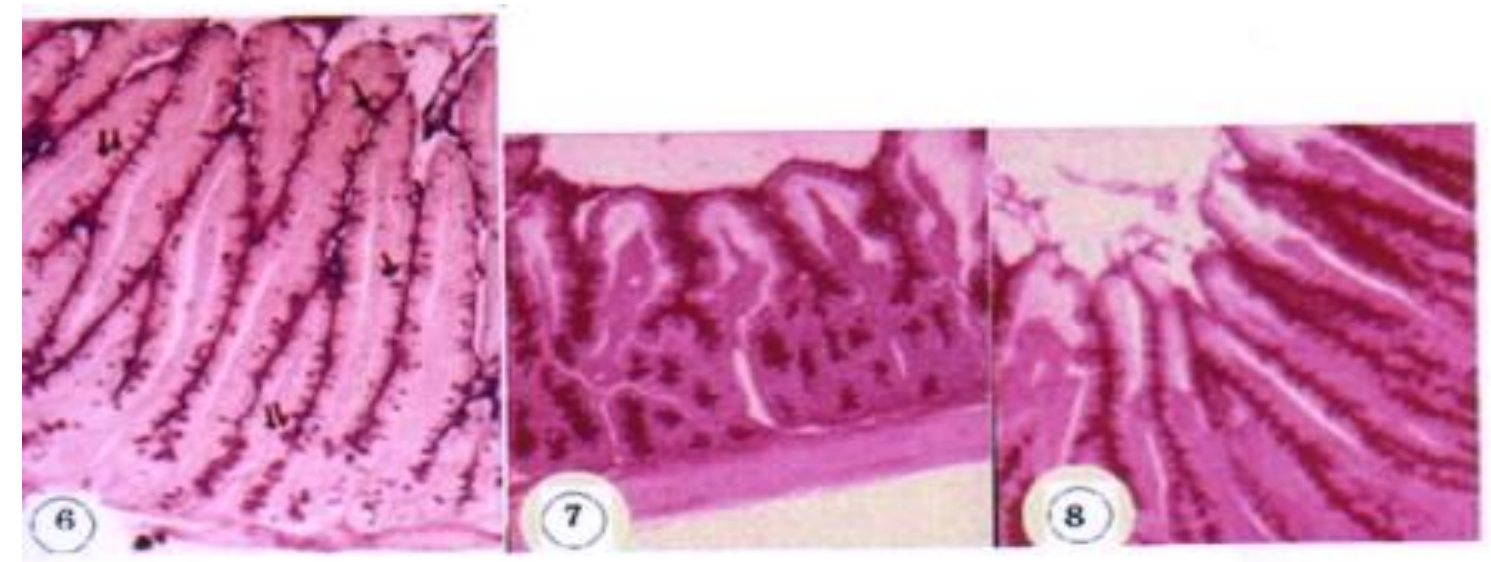

Plate II: Goblet cells in the villi and crypts of 6) Control, 7) infected animals two weeks post infection, 8) Immunized infected animals two weeks post infection.

(PAS, alcian blue X100)

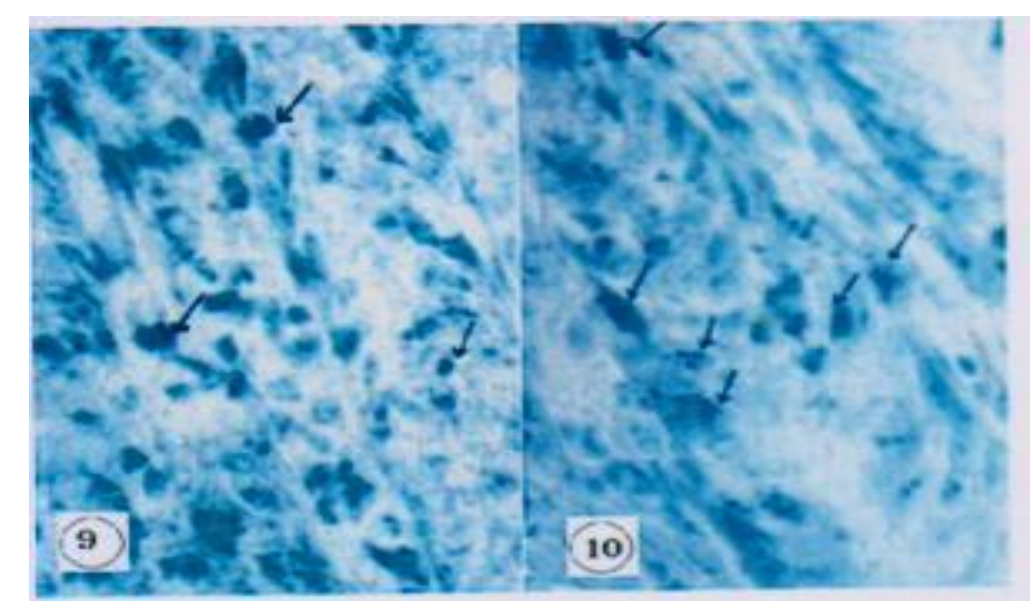

Plate III: Mast cells at two weeks post infection 9) non-immunized infected group 10) immunized-infected animals

(Toluidine blueX400)

\section{Quantitative Evaluation:}

\section{Worm Burden}

The change in worm burden after infection in non-immunized and immunized groups over the period of the experiment was used as a criterion for parasite infection. The worm burden at zero point was considered zero.

In figure 1-4, the worm burden has reached its beak value after one week. It started to decline over the next two weeks as the worms invade the mucosa. In the immunized group, there was $67 \%$ decrease in worm burden compared with the non immunized group (table 1, figure 6).

\section{Female worm Fecundity}

The in vitro evaluation of the female worm fecundity indicated a $38 \%$ decrease in the number of larvae emerging from adults isolated from immunized compared to those isolated from non-immunized rats (table 1).

\section{Villus/crypt Ratio:}

In non-immunized group, there was a decrease in the mean ratio of the length of the villus relative to crypt length (figure 1). The least value was obtained on the second week after infection; after which a relative increase was obtained. The rate of the decrease in this ratio was $78 \%$ less after immunization. 


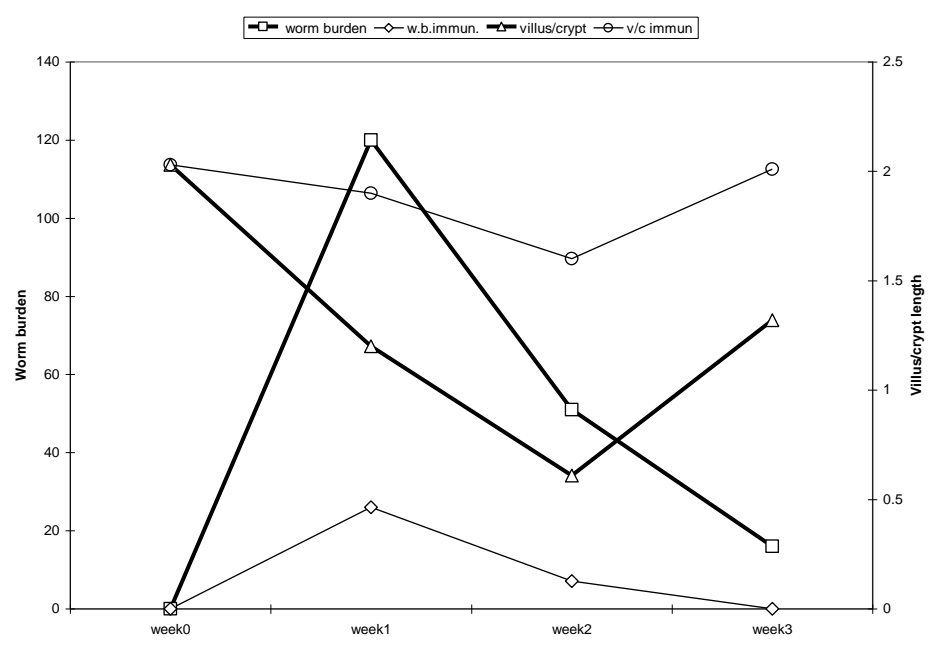

Figure (1): The change in the villus/crypt ratio in relation to the worm burden, over 3 week period, in rats infected by $T$.spiralis with or without immunization by adult worm antigen. The values for the control were considered as week zero. The villus crypt ratio is inversely proportional to the worm burden. The least value was obtained one week after the peak of the maximum worm burden.

\section{The number of Goblet cells}

Infection with T.spiralis, resulted in an increase in the number of goblet cells per unit area of the villar surface (table 2). The maximum value was obtained on the second week, one week after the maximum worm burden (figue 2). In immunized group the increase in the number of goblet cells was $13.3 \%$ more than in the nonimmunized group (table 1).

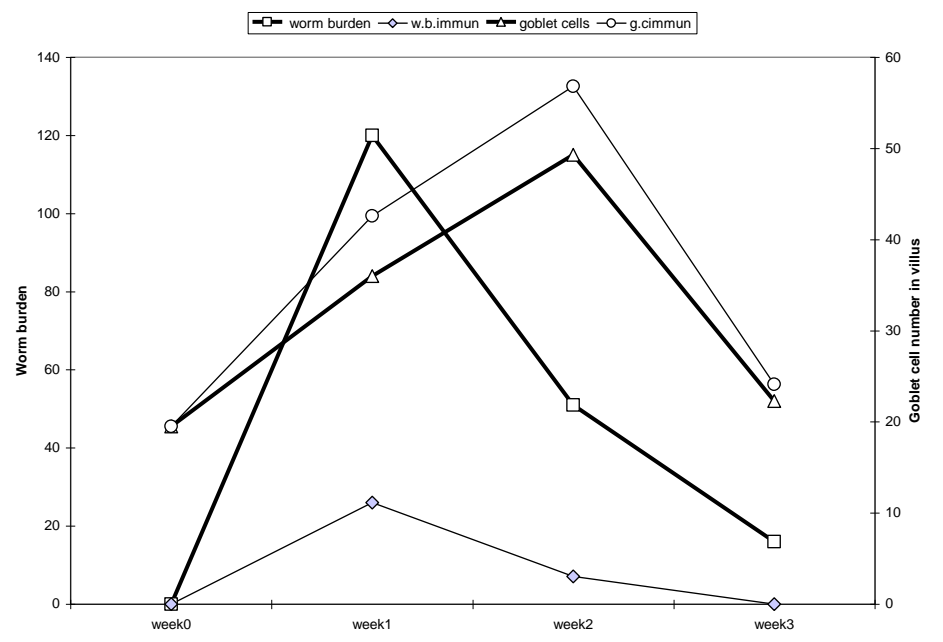

Figure (2): The change in the number of goblet cells in the villi in relation to the worm burden, over 3 week period, in rats infected by T.spiralis with or without immunization by adult worm antigen. The values for the control were considered as week zero. The villus goblet cell number is directly proportional to the worm burden. The highest value was obtained one week after the peak of the maximum worm burden.

The trend in the change in the number of goblet cells in the crypts was similar to that of the villi (table2, figue 3). However, the rate of increase after two weeks was more in crypts than villi. The percent increase in the number of crypt goblet cells after immunization was $16.22 \%$. 


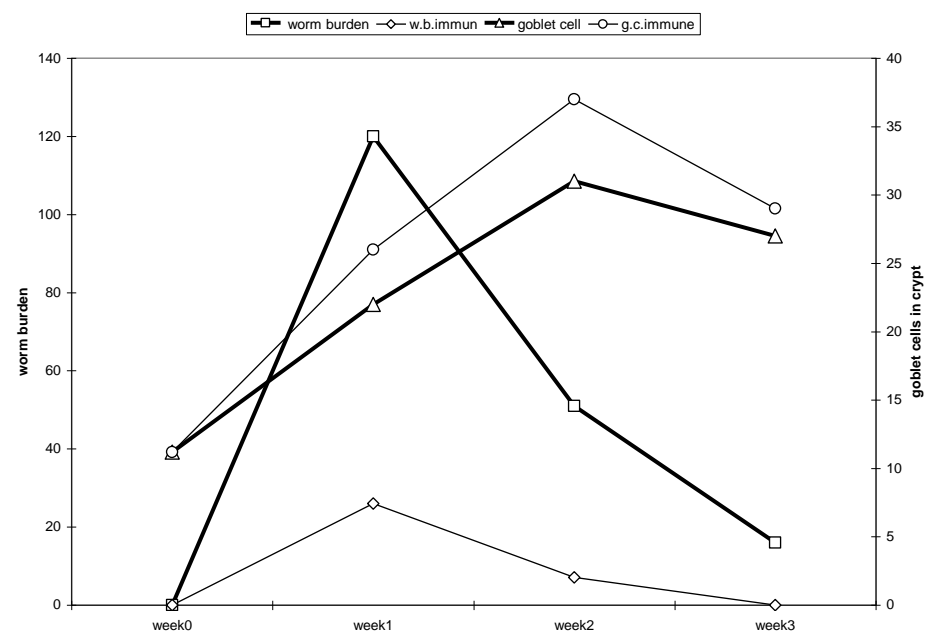

Figure (3): The change in the number of goblet cells in the crypts in relation to the worm burden, over 3 week period, in rats infected by T.spiralis with or without immunization by adult worm antigen. The values for the control were considered as week zero. The crypt goblet cell number is directly proportional to the worm burden. The highest value was obtained one week after the peak of the maximum worm burden.

\section{The number of Mast cells}

The number of mast cells per unit area in the lamina propria of the jejunum of infected rats was proportional to the increase in the worm period. The peak however was obtained after two weeks of infection (table2, figure 4). In immunized rats the value of mast cell number was higher than in non-immunized. The increase at the peak value was $22.5 \%$.

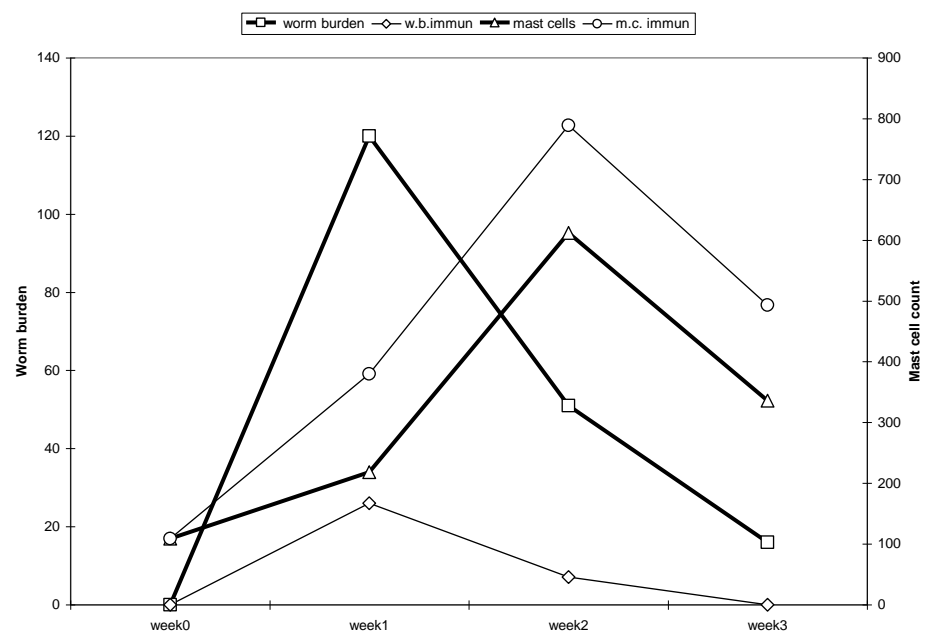

Figure (4): The change in the number of mast cells in intestinal mucosa in relation to the worm burden, over 3 week period, in rats infected by T.spiralis with or without immunization by adult worm antigen. The values for the control were considered as week zero. The mast cell number starts with a lag phase in the first week in non immunized rats. The number is higher without lag period in immunized rats. It is directly proportional to the worm burden. The highest value was obtained one week after the peak of the maximum worm burden. 


\section{The Histamine content}

The histamine content was directly proportional to the mast cell number (figure 5).

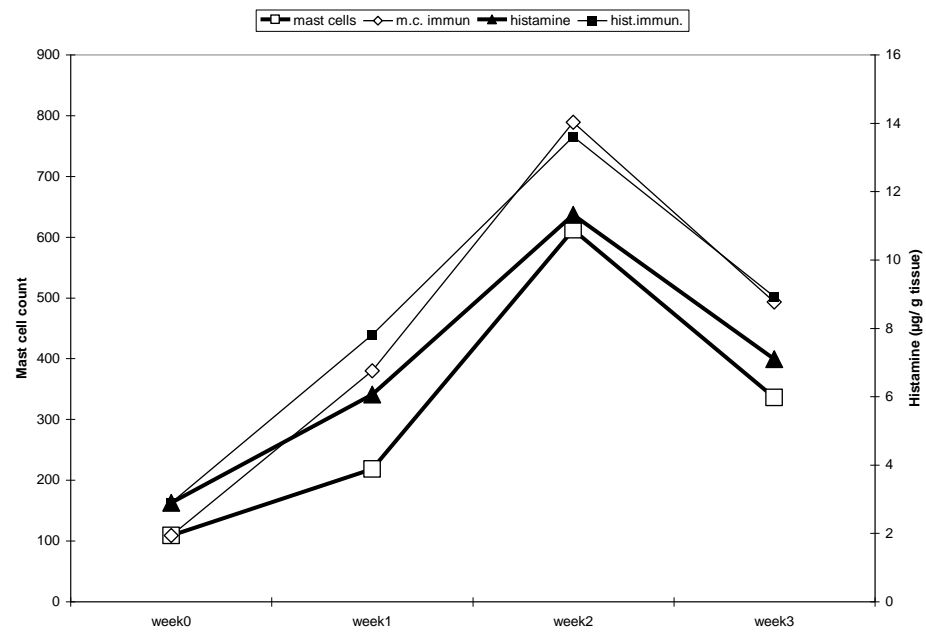

Figure (5): The change in the number of mast cells in intestinal mucosa in relation to histamine content, over 3 week period, in rats infected by T.spiralis with or without immunization by adult worm antigen. The values for the control were considered as week zero. The lag phase is less pronounced in the amount of histamine. The relationship between mast cell number and histamine content is clearly demonstrated.

As in mast cell number, immunization resulted in an increase in histamine (table 2). The increase, however, was slightly less than that of mast cell number (table 1) suggesting an increase in cell proliferation not accompanied by similar increase in histamine secretion.

Table (1): Percent protection due to immunization of T.spiralis infected rats.

\begin{tabular}{|l|l|l|l|l|l|l|l|}
\hline Parameter & $\begin{array}{l}\text { worm } \\
\text { burden }\end{array}$ & $\begin{array}{l}\text { Larval } \\
\text { emergence }\end{array}$ & $\begin{array}{l}\text { Villus/Crypt } \\
\text { ratio }\end{array}$ & $\begin{array}{l}\text { Villus } \\
\text { goblet } \\
\text { cell count }\end{array}$ & $\begin{array}{l}\text { Crypt } \\
\text { goblet } \\
\text { cell count }\end{array}$ & $\begin{array}{l}\text { Mast cell } \\
\text { count }\end{array}$ & $\begin{array}{l}\text { Histamine } \\
\text { content }\end{array}$ \\
\hline $\begin{array}{l}\% \text { of non } \\
\text { immunized } \\
\text { on 2 }\end{array}$ & 67 & 38 & 78 & 13.3 & 16.22 & 22.5 & 16.8 \\
\hline
\end{tabular}

Table (2): Mean numbers of goblet cells, mast cell /10 vcu of jejunal villi and Crypts and intestinal histamine in studied group

\begin{tabular}{|l|l|l|l|l|l|}
\hline Groups & w.p.i & $\begin{array}{l}\text { goblet } \\
\text { cell/villus }\end{array}$ & $\begin{array}{l}\text { Goblet cell/ } \\
\text { crypt }\end{array}$ & $\begin{array}{l}\text { Mast cells } \\
\text { 10vcu }\end{array}$ & $\begin{array}{l}\text { Histamine } \\
\text { content ug/ gm } \\
\text { tissue }\end{array}$ \\
\hline Control & & $19.5+1.6$ & $11.2+1.1$ & $109+23$ & $2.89+1.23$ \\
\hline & 1 & $36+03^{*}$ & $22+1.2^{*}$ & $218+36^{*}$ & $6.06+0.03^{*}$ \\
non- & 2 & $49.3+3.7^{*}$ & $612+17^{*}$ & $612+17^{*}$ & $11.32+3.1^{*}$ \\
immunized & 3 & $22.3+1.8$ & $336+28^{*}$ & $336+28^{*}$ & $7.1+1.6^{*}$ \\
\hline & 1 & $42.6+0.1^{*}$ & $26+0.8^{*}$ & $380+18^{*}$ & $7.81+2.1^{*}$ \\
Immunized & 2 & $56.8+0.18^{*}$ & $37+1.8^{*}$ & $789+20^{*}$ & $13.61+2.4^{*}$ \\
& 3 & $24.1+0.03$ & $29+0.2^{*}$ & $493+0.01^{*}$ & $8.92+0.06^{*}$ \\
\hline
\end{tabular}

$\mathrm{P}<5.05-0.01$ in GII and III compared by control using chi-square test 


\section{Azza A. Elnokaly \&Abdel-Mawgoud A. Ismaeil}

\section{Discussion}

Trichinosis can be fatal in the case of infection with high number of worms (Macleod, 1984). Trichinosis became of interest to Egyptian physicians after the recent discovery of Trichinella spiralis infection of lamb meat (Rosa et al., 1992; Kim, 1993; and Theodoropoulos et al., 2000).

The maximum number of worms were recorded in the intestinal mucosa one week post infection. This time coinsides with the time needed for the development of sexually mature adults (Campbell et al.,1999). Immunization with 2 successive subcutaneous injection of $100 \mu \mathrm{g}$ crude adult worm antigen I week apart followed by challenge infection by 300 infective T.spiralis larvae resulted in a significant reduction in worm burden compared to the infected non-immunized. The protection was $67 \%$. In addition, $38 \%$ protection resulted from the effect on female worm fecundity with complete worm expulsion by the end of 3 rd w.p.i. Similar results have been published by Ortega-Pierres et al.(1986) and Darwish et al.(1996).

The interpretation of the reduction in adult worm burden draws a clear conclusion that the immune status created by prior immunization enhances the overall protective immunity of the host against $T$. spiralis infection. This protection could be through several mechanisms including limitation of fecundity of female worms as indicated in the present work, or elimination of circulating newborn larvae but clearly not through rapid expulsion of adult worm. (Murrell,1985). The antifecundity effect may be due to the gut immune response induced by the injected antigens (Murrell,1985), Inflammatory events in the intestinal tissues (Darwish et al.,1996), and attack of the male organ, being cuticular in nature, by antibodies elicited by injected antigen will interfere with fertilization of the female with subsequent affection on fecundity (Ortega-Pierres et al.,1986).

The morphological and morphometeric measures of the intestinal mucosa of the studied groups showed that, in nonimmunized rats, a significant decrease in villus/crypt ratio is observed and reached its peak by the end of the 1st w.p.i. Gross inflammatory changes in the intestine could be involved in the shortening of the villi of infected group. Similar changes were also reported by Uber et al. (1980), Alizadeh\&Wakelin (1982) and Sayed ElAhl et al.(2001).

Expulsion of the adult worms of $T$.spiralis by the host seems to be an ambiguous multi factorial process but involvement of certain antibodies and cytokines is well recognized lately (Bell,1998). In addition, there seems to be a possible role of epithelial cells in the protective immune response to T.spiralis manifested by observation of modified epithelial cell structure and function during a challenge infection. These changes includeed reduced wheat germ lectin binding to the epithelial brush border membrane in infected rats (Bell,1998).reduced hexose transport (Hessel et al., 1982), increased potential difference across epithelial tight junctions (Russell\&Castro,1985), and chloride ion secretion, which is linked to a change from fluid uptake to net fluid secretion by enterocytes (Bell,1998). The functional changes in epithelial cells described in these studies have been linked to the immune system through immune serum transfer (Bell,1998).

The number of goblet cells of infected rats progressively increased to reach a peak value by the end of the first week. Similar observations were reported by Friend et al.(1996) and Miller (1996). The increase in goblet cells mean number was accompanied by an increase in acid mucin. These quantitative and qualitative changes facilityated the expulsion of worms completely by the $3^{\text {rd }}$. w.p.i in immunized group. Koninkx et al. (1988) attributed the increase of acid mucin to the increase in the number of sulfomucin-contaning goblet cells. Khan et al. (1995) reported that intestinal mucus contributes to the immune-mediated prevention of establishment of parasites.

A significant increase in the mean number of mast cells was recorded over the three weeks of the experiment which indic- 
ates the precise role played by these cells in worm expulsion. The effect of immuneization was manifested in the form of enhancement of mastocytosis. Recently interpretations of mucosal mast cell involvement in worm expulsion were necessarily based upon quantitative data from histological preparations of intestinal tissue. Although such an approach allows correlations to be made between the kinetics of infection and changes in the number of mucosal mast cells present, yet it dose not measure mucosal mast cell function directly. In the present study, mucosal mast cell activity was quantified by measuring histamine content in the intestinal tissues. In the gastrointestinal tract and at the cellular level, histamine is found largely in mast cells, mast cell like histaminocytes and in acid secreting glands in the stomach (Range \& Dale,1991). Release of cytokines has been proposed as a mechanism in immune response in trichinosis. Ridlinger et al. (1996) first characterized the cytokine profile in immunized mice including IL-2 and IL-3 which could induce mastocytosis and enhanced eosinophilia. Bell (1998) reported that IL-3 is the most important cytokine that can influence mast cell numbers.

In conclusion, The histological and morphometric data support the parasitological data that immunization with worm antigen ameliorates the danger of trichinosis.

\section{References}

1. Alizadeh, H. and Wakelin, D. (1982): Comparison of rapid expulsion of $T$. spiralis in mice and rats. Int. J. Parasitol., 12: 65-7.

2. Bell, R.G. (1998): The Generation and expression of immunity to $T$. spiralis in laboratory rodents. Advan Parasital., 4!: 149-217.

3. Campbell NA, Reece JB and Mitchell LG., (1999): Biology $5^{\text {th }}$ ed.Benjamin/ Cummings, Menlo Park, Ca.

4. Darwish, R.A.; Sanad, M.M. and Youssef S.M. (1996): Immunization against $T$. spiralis using anti gens from different life cycle stages: Experimental study in mice. J. Egypt. Soc. Parasitol., 26 (1): 19-26.

5. Friend, D.S. Ghildyal N.; Austen, K.F.; Gurish, M.F.; Matsumoto, R. and
Stevens R.L. (1996): Mast cells that reside at different locations in the jejunum of mice infected with T. spiralis exhibit sequential changes in their granule ultrastructure and chymase phenotype. Journal of Cell Biology, 135: 279-299

6. Gamble, H. R. and Murrell, K.D. (1987): Progress in the development of vaccines against parasitic diseases. Immunology letters, 16: 329-336

7. Gamble, H.R. (1985): Comparison of immune effect in mice immunized with the T. spiralis adult and larval antigen. Immunology letters, 9: 211-2

8. Goyal, P.K. and Wakelin, D. (1993): Influence of variation in host strain and parasite isolate on inflame-matory and antibody responses to $\mathrm{T}$. spiralis in mice. Parasitology 106, 371-378 kkh

9. Hessel, J., Ramaswamy, K. and Castro, G.A. (1982): Reduced hexose transport by enterocytes associated with rapid, noninjurious rejection of $\mathrm{T}$. spiralis from immune rats. Journal of Parasitology 68, 202-207

10. Khan, W.; Abe, T.; Ishikawa, N.; Nawa, Y. and Yoshimura, K. (1995): Reduced amount of intestinal mucus by treatment with anti-CD4 antibody interferes with the spontaneous cure of. Nippostronglus brasiliensis infection in mice. Parasite Immunol., 17: 485-491.

11. Kim, C.W. (1993): A decade of progress in Trichinellosis. In: Campbell, W.C. Pozio, E. and Bruschi, F. eds Trichinellosis. The 8th Inter. Conference on trichinellosis

12. Koninkx, J.F.; Mirck, M.H. Hendriks, H.G. Mouwen, J.M.; and Van Dijk, i.E. (1988): Nippostron - gylus brasiliensis: Histochemical changes in the composition of mucins in goblet cells during infection in rats. Experimental Parasitology, 65: 84-90

13. Leiby, D.A.; fluffy, C.H.; Murrel, K.D. and Schad, G.A. (1990): T. spiralis in agricultural ecosystem transmission in the rat population. J. Parasitol. 76: 360-364

14. Lorenz, NV.; Barth, H.; Kusche, J.; Reimann, H.J.; Schmal, A.; Matejka, E.; Mathias, Ch.; Hutzel, M.and Werle. E. (1977): Histamine in the pig: determination. Eur. J. Pharmacol., 14: 155-175

15. Lowry, O.H.; Rsebrough, N.J.; Farr, A.L. and Randall, R.J. (1951): Protein measurment with the Fol in phenol reagent. Journal of Biological Chemistry, 193: 265275

16. Macleod J, (1984): Davidsons principles and practice of Medicine., $14^{\text {th }}$. ed. Churchill Livingstone, Edinburgh. 
17. Miller, H.R. (1996): Mucosal mast cells and the allergic response against nematodes parasites. Vet. Im munol. Immunopathol., 54: 33 1-336.

18. Mowry, R.W. (1958): Alcian blue techniques for histochemical study of acidic carbohydrates. J. Hist. Cytochem., 6: 82-90

19. Murrell, K.D. (2001): Trichinellosis: Now and for ever moie? Parasite. 8: S11-S13.

20. Ortega-Pierres, G.; Clark, N.W. and Parkhouse, R.M. (1986): Regional specialization of the surface of a parasitic nematode. Parasite Immunol., 8: 613-617.

21. Piergili-Foretti, G.; Moretti. A., Marini, C. and Antognoni, M.T. (2001): Trichinelkz spp. In ostriches meat: A public health risk?. Parasite., 8: S203-S205

22. Pozio, E.; Tamburrini, A. and La Rosa, G. (2001): Horse trichinellosis and unresolved puzzle. Parasite. 8: S263-S265.

23. Range, H.P. and Dale, M.M. (1991): Pharmacology, 2nd ed. Churchill Livingstone: Medical division of Longman Group. UK Ltd

24. Riedlinger, J. Grencis, R.K. and Wakelin, D.(1986): Antigen-specific T-cell lines transfer protective immunity against T. spiralis in vivo. Immunology 58, 57-61.

25. Rollinson D and Anderson, R.M. (1985): Ecology and genetics of host-parasite interactions. Academic Press, London

26. Rosa, C.L.; pozio,.E.; Rossi, P. and Murell, K.D. (1992): allozyme analysis of Trichinella isolates from various host species and geographical regions. J. Parasitol 78 641-646

27. Russell, D.A. and Castro, C.A. (1985): Anaphylactic-like reaction of small intestinal epithelium in par asitized guineapigs. Immunology 54, 573-579.

28. Sayed El-Ahl, S.A., E1-Shafei, A.A., Salem, M.A. and Ali, E. B. (2001): Functional study On goblet cells and mast cells activities during Trichineila spiralis expulsion in infected albino rats. Egypt. J. Comp. Path. \& Clinic. Path., 1: 102-123.

29. Theodoropulos, G.; Kapel, C.M.O. and Webster, P. (2000): Experimental trichinellosis in sheep. Xth Inter. Conf. Trichinellosis, Fontainebleau (France).

30. Uber, C.L.; Roth, R. L. and Levy, D. A. (1980): Expulsion of Nippostrongylus brasiliensis by mice deficient in mast cells. Nature, 287-298.

31. Viveros, N.; Arriaga, C.; Banda, V.; Ortega-Pierres, M.G. and yepez-Mulia, L. (2001):Detection of Trichinella infection in slaughter horses by artificial digestion, ELISA and PCR. Parasite, 8: S257S259.

32. Wakelin, D. (1993): Allergic inflammation as a hypothesis for the expulsion of worms from tissues. Par-asitology Today 9, 115116.

33. Wang, C.H. and Bell, R.G. (1987): Trichinella spiralis: Intestinal expression of systemic stage-specific immunity to newborn larvae. Parasite Immunology9: 465-475.

34. Wassom, D.L., Brooks, B.O., Cypess, R.H. and David, C.S. (1983): A survey of susceptibility to infection with $\mathrm{T}$. spiralis of inbred mouse strains sharing common $\mathrm{H}-2$ alleles but different genetic backgrounds . Journal of Parasitology 69, 1033-1037 


\title{
الأستجابة المعوية للترايكينوزس فى الفأر الأبيض المحصن والغير المحصن
}

\author{
عزة عبد الرحمن النقلى , عبد الموجود أنس اسماعيل \\ من قسم الطفيليات و الههنتولوجيات المبوديا \\ كلية طب بنين وبنات - جامعة الأزهر
}

لقد وجد ان هناك علاقة بين الغشاء المبطن للامعاء الدقيقة و الاصـابة بدودة التر ايكينلاسيبر اليز

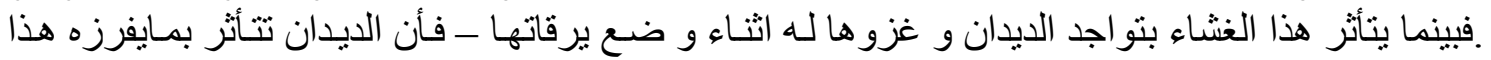

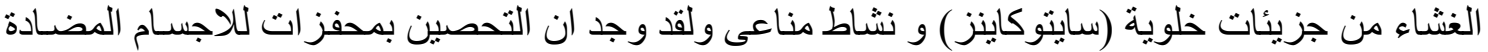

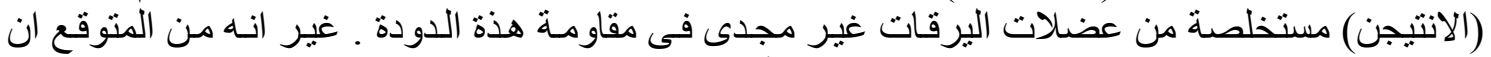

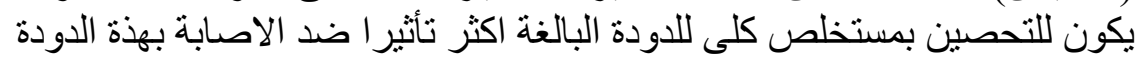

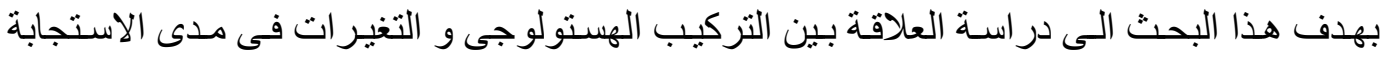

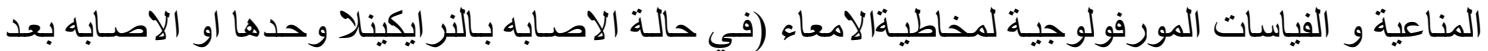

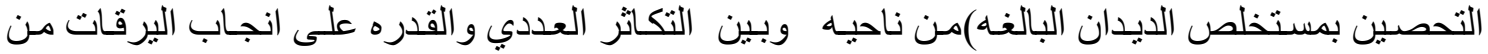

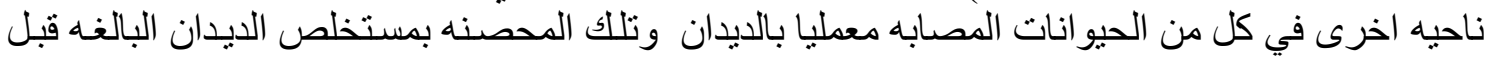

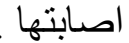

حيث من المتوقع ان تؤدي مثل هذه الدر اسه الى تقييم أفضل لتأثير التحصين بهذا المستخلص.

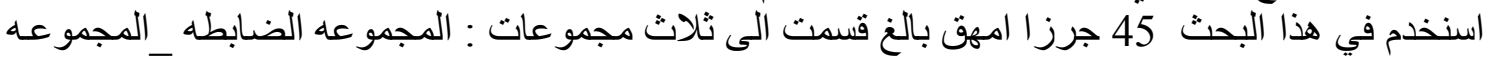

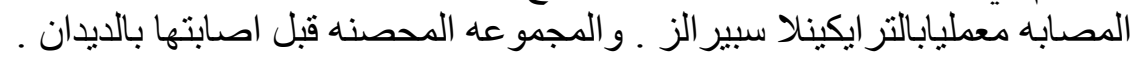

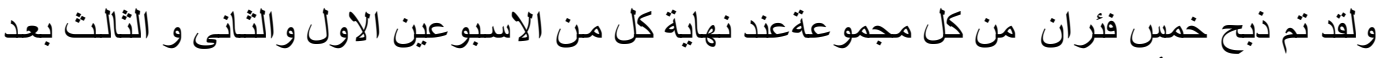

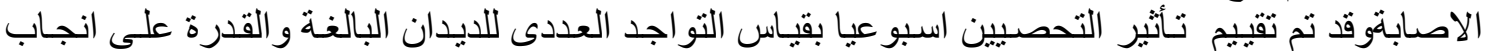

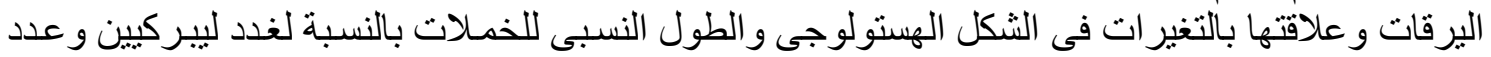

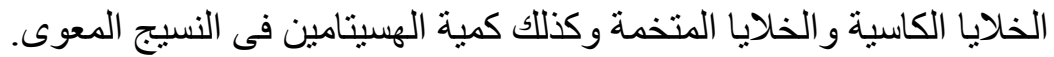

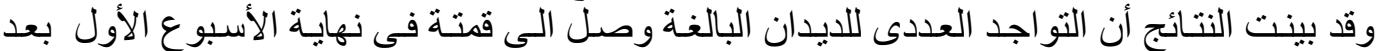

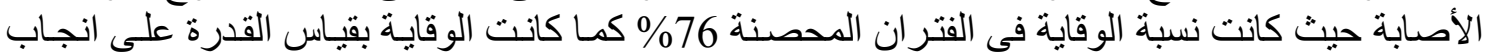

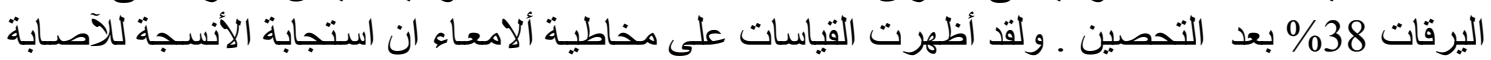

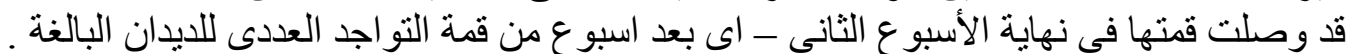

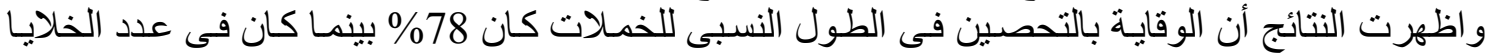

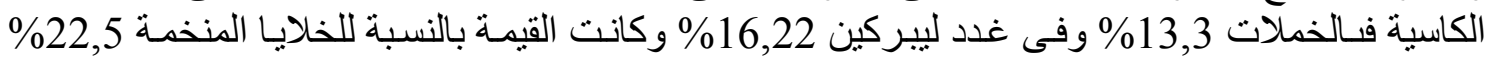

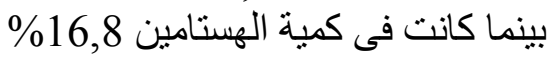

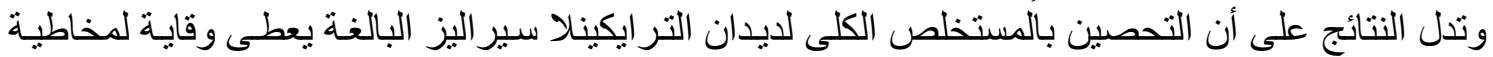

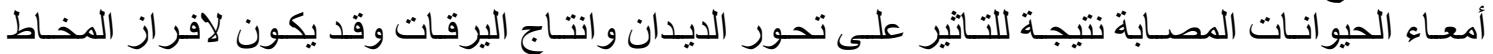

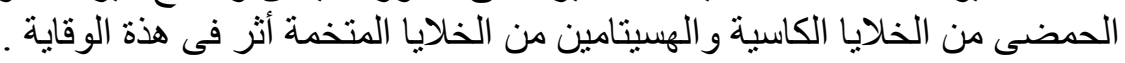

